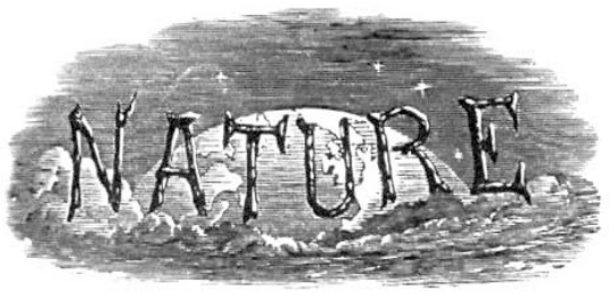

THURSDAY, MAY 5, I92I.

Editorial and Publishing Offices:

MACMILLAN \& CO., LTD.

ST. MARTIN'S STREET, LONDON, W.C.2.

Advertisements and business letters should be addressed to the Publishers.

Editorial communications to the Editor.

Telegraphic Address: PHUSIS, LONDON.

Telephone Number: GERRARD 8830.

\section{Physics a Profession.}

$\mathrm{F}$ IFTY years ago, as Sir J. J. Thomson pointed out in his address at the inauguration of the Institute of Physics on April 27, there could be no profession of physics. There were a few laboratories--the oldest at the Royal Institution, founded by Count Rumford; the home of Young and Faraday. They could be counted almost on the fingers of the two hands. There were laboratories in Scottish universities. Kelvin was at work at Glasgow, Tait at Edinburgh, Balfour Stewart at Manchester, Carey. Foster was teaching at University College, London, Clifton had built the Clarendon Laboratory at Oxford, Maxwell had only recently resigned his professorship at King's College (he went to Cambridge in $187 \mathrm{I}$ ). The Cavendish Laboratory was being planned; the seventh Duke of Devonshire had written to the Vice-Chancellor :

"I find in the report . . recommending the establishment of a professor and demonstrator of experimental physics that the building and apparatus required for this department are estimated to cost $6300 l^{i} \mathrm{I}$ am desirous to assist the University in carrying this recommendation into effect, and shall accordingly be prepared to find the funds required for the building and apparatus."

1 The tender ultimately accepted for the buildinz was $8450 l$ exclusive of gas, water, and heating.

No. 2688 , VOL. IO7]
Maxwell, in his inaugural lecture, said:

"Our principal work in the laboratory must be to acquaint ourselves with all kinds of scientific methods, to compare them and estimate their value. It will, I think, be a result worthy of our University, and more likely to be accomplished 'here than in any private laboratory, if by the free and full discussion of the relative value of different scientific procedures we succeed in forming a school of scientific criticism, and in assisting the development of the doctrine of method."

Physics as a profession by which numbers of men would earn a livelihood and at the same time revolutionise the daily life of the world by bringing into it knowledge acquired in the laboratory and the study never entered Maxwell's thoughts. Contrast this, as Sir Joseph Thomson did, with the position at present-a university or technical school in almost every great town, each with its well-equipped physical laboratory, its keen professor and its enthusiastic students; laboratories in all the larger schools, with a staff of teachers numbering many hundreds. Fifty years ago the army of physicists was small in numbers; its generals were great men, but they had few of the rank and file to command. To-day our leaders in physical science have under their direction a host of willing privates ready to assist in advancing further the boundaries of knowledge and to adapt the discoveries of those leaders to the requirements of modern life. So it has come about that an Institute of Physics was needed; the attendance at the inaugural meeting on April 27 gave evidence of the need; for there is now a profession of physics.

"Up to the present," to quote from the memorandum explaining the objects and methods of the institute, "the physicist has hardly been recognised as a member of one of the professions. His work will become more and more important in the future both in science and industry, and one of the airns of the institute is to accelerate the growth of the recognition of his position and value. The science of chemistry has already secured a belated recognition of its value to the nation, but there has been so far little or no recognition of the equally important claims of physics and the physicist, although the application of physical knowledge and physical methods is no less vital to the country."

Both Mr. A. J. Balfour and Sir Joseph Thomson placed physics on a higher pedestal than this. Mr. Balfour pointed out that to give a physical explanation of a phenomenon was one of the highest aims of scientific inquiry, and Sir Joseph reminded us that at Cambridge not many years 
ago chemistry was counted one of the "other branches of physics."

Some of us in the early days of the war faced very sadly the difficulty of bringing home to some of our rulers the value of physics and the services physicists could render. Five years of trial have enforced the lesson, and now it is widely realised that in many branches of work the physicist is able to give much-needed help; opportunities are open to him in widely different directions.

It may be useful to consider some of these. Fifty years ago a few ill-paid teaching posts were all to which a physicist could aspire. The love of discovery, the desire to fathom the secrets of Nature, to give a physical explanation, bringing into their due relation facts apparently disjointed and diverse, brought their own reward-a reward sufficient for the few who devoted their lives to science. And this still remains. Much has been learned; but Nature still hides many secrets, and for the man who can unravel these there is still an ample reward. But the task of nearly all professional physicists must be humbler far. They: can assist the work of the discoverer by reducing the period of suspense which, as Sir Joseph Thomson pointed out, will always elapse between a great discovery and the full realisation of its meaning; they can check some of its consequences, indicate the directions in which it may be of service, or carry out supplementary investigations under the guidance of the discoverer himself.

Such would be the work of the young student in the university laboratory training for his profession. And the openings in that profession are very numerous; at present it is hard to find men to fill them; the heads of the fighting Services have realised their need of the physicist. At Woolwich there is a well-equipped laboratory employing a number of highly skilled men. Gunnery has its problems which only the trained physicist can solve, and calls to its assistance the help of the meteorologist and the engineer. Sound ranging, the methods of protection against aircraft, signalling, the use of wireless telegraphy, the application of the petrol engine to transport work, and a host of other questions, are examples of the need for physicists in military work.

Nor is the Air Service less dependent on the physicist. Questions which he alone can solve are brought before every meeting of the Aeronautical Research Committee, and it is only lack of funds that prevents a far larger number NO. 2688 , VOL. IO7] of physicists from being employed at the National Physical Laboratory, at Farnborough, and at the other experimental stations of the Air Ministry.

In the Naval Service steps have lately been taken to organise more fully the Scientific Services. Mr. F. E. Smith, the recently appointed Admiralty Director of Scientific Research, gave some account of these at the Cardiff meeting of the British Association last August. For certain parts of the work it is hoped to utilise the opportunities afforded by the National Physical Laboratory, and an admirable building has been erected at Teddington in which work of a strictly confidential character can be carried on; the Signal School at Portsmouth has been reorganised; while work on the petrol engine, commenced during the war under Sir Dugald Clerk at the Imperial College, is now being continued in a special Admiralty laboratory.

Other Government Services, as well as private firms and individuals, have access to the National Physical Laboratory, where, according to the last report, well over one hundred scientific assistants are employed. In the Government service alone there is now engaged a large class of professional physicists occupying permanent posts with reasonable opportunities for advancement and, in the majority of cases, superannuation privileges.

Or, again, turning to another class of service, many, possibly most, of the Research Associations established under the Department of Scientific and Industrial Research depend on the physicist for their investigations, while in almost every large industry there is a demand for his work. The need for an Institute of Physics to care for the professional interests of the large number of men who have already embraced the profession, and of the still larger number who will be required so soon as trade revives, and may hope by their work to advance the date of its revival and to accelerate its progress, is amply proved. The object of the institute will be to promote the efficiency and usefulness of its members by setting up a high standard of professional and general education and knowledge, and by compelling the observance of strict rules of personal conduct as a condition of membership; an association of men who, in Mr. Balfour's words, "by the growth of science and invention would give comfort and leisure where at present discomfort and labour were the only means of producing an article," and by their example would teach our people how to use their leisure. 